\title{
Internet environment under the Asset Securitization Financing Model
}

$$
\text { XIN Yufei }{ }^{1,} \mathrm{a}^{*} \text {, SHENG Zhonglin }{ }^{2} \text { and LIU Kang }{ }^{3}
$$
${ }^{1,2}$ Dongling School of Economics and Management University of Science and Technology, Beijing
100083, China

${ }^{2}$ School of Software \& Microelectronics, Beijing 100871, China

a workbooking@126.com

Keywords: Asset securitization; infrastructure development; feasibility; Problems and Solutions.

\begin{abstract}
Asset securitization is the last decade of the largest and fastest growing international financial sector financial instruments and means of financing in infrastructure construction using asset securitization financing of this new model has the reach advantage of other modes, to solve China's infrastructure shortage of funds in the field of construction has a positive effect immeasurable. China in the implementation of infrastructure projects of asset securitization financing models already have the conditions for implementation. But in the SPV formation, the tax system, foreign exchange balance and financial environment and other issues are still many problems, the urgent need to establish the appropriate support mechanisms to solve them.
\end{abstract}

\section{Asset Securitization and infrastructure}

\section{Asset Securitization definition and characteristics}

Asset securitization (referred to ABS) is the last decade of the largest and fastest growing international financial sector financial instruments and financing instruments. It originated in the 1970s, the US housing mortgage securitization, in 1970, under the United States Government National Mortgage Association, the government issued its first mortgage-backed securities (MBS) in order to guarantee mortgage loans, creating a precedent for securitization .

1980s to the 1990s, this financing tool is available on the US and European market is growing rapidly, and enter the Asian market, and formed a considerable scale of the asset securitization market. So far, however, scholars from various countries of asset securitization is still not a unified, precise definition. From different angles and viewpoints asset securitization have a different interpretation of the results. As JosephC.Shenker \& AnthonyJ representative proposed definition is: "Asset Securitization refers to the sale of shares or debt obligations of the equity or debt certificates represents an independent, property or the collection of revenue streams in the ownership interest or for which they are secured, the transaction is architecture to reduce or reallocate risk when these basic own or lease property, and to ensure that these assets more market-oriented, so that more than just have the basic ownership interest in the property or claims to have more liquidity. "US Securities and Exchange Commission (SEC) that the asset securitization was" founded by a group of major discontinuities receivables or other financial assets to generate cash flow set backed securities, which may be fixed or cycle and it can be realized in a period of time under the terms, while some additional rights or other assets to enable such guarantees or on time to bond holders assigned revenue. " Nevertheless, the application of asset securitization is still expanding. Asset Securitization refers to illiquid assets owned by the project objectives as the basis for the future of the project assets expected return guarantee, through the issuance of high-grade bonds in the international capital markets to raise funds for a project financing. Asset Securitization applied to infrastructure construction, it refers to future cash receipts as a guarantee infrastructure projects provided with necessary letter enhancement measures, issuing long-term bonds and other securities in the capital markets in order to obtain funds for construction financing.

Compared with other traditional modes of financing, asset securitization financing has the following characteristics: (1) low financing costs. Total asset securitization financing costs lower than traditional financing methods, the reason is: First, the use of sophisticated asset securitization 
transaction structure and credit enhancement means to improve the conditions of issuance of securities. Since the asset-backed securities have a higher credit rating, do not discount the sale or use other means to raise interest rates to attract investors, under normal circumstances, can be asset-backed securities at a price higher than or equal to the face value of the issue, and the rate of interest paid ratio comparable securities issued by the originator is much lower, it is more greatly reduces the originator's financing costs. Second, asset securitization expenses of the project, although many, but the ratio of the total costs associated with the transaction is low; (2)High efficiency financing. Asset securitization as a financing tool to help sponsors, is unique in that it can be used financier their future earnings to finance, from the general financing instruments will be used for financing the property's existing financing. Asset securitization financing people can transfer their right to future earnings or debt, obtain financing at sight, which is very beneficial to improve cash flow and flexible use of funds; (3)Small investor risk. In general, investors difficult to operators to carry out effective monitoring. In asset securitization, investors only invest in specific securities, the choice of the underlying assets can reduce investment risk. Unless the economy as a whole frustrated, or else risk a particular asset is that it can be controlled or prevented. Therefore, because of its small asset securitization risk, to attract more investors, to attract more funds; (4)Wide scope of application. Asset securitization is a structured financing, the issuer by constructing a rigorous transaction structure to achieve the purpose of financing. Between financiers and investors additional SPV (SpecialPurposeVehicle), as portfolio holders and issuers, to ensure the smooth operation of asset securitization credit enhancement and risk isolation mechanism. As long as there are good assets, stable cash flow, regardless of loss or business can be so outstanding financing. This unique structure contributed to the asset securitization widely used.

\section{Infrastructure used in asset securitization financing superiority}

With the rapid development of world economy, backward infrastructure as a constraint to a country's economic development bottleneck. Construction of education, health, legal and other human infrastructure and transport, energy, communications, and other substances of infrastructure deficiencies will directly affect the environment and economic development of a country's investment environment, the country unattractive. Asset securitization in infrastructure use can ease the problem of insufficient funds in a way. First, asset securitization through credit enhancement so that the original credit rating lower infrastructure project assets into the international high-end security market, issuance easy sell, assign and discount ability of high-grade bonds. The diversification of sources of funds in the market, the lower interest rate debt, coupled with fewer asset securitization involves link, thereby reducing financing costs, greatly reducing the honoraria and fees. Second, asset securitization financing broaden the financing channels national infrastructure projects, bridges since the framework of private capital and infrastructure between the contradiction resolved scattered private capital and large-scale infrastructure construction needs huge amounts of money between . The same time as high-grade bonds issued on the international stock market is not purchased by a particular majority, thereby dispersing the investment risk. In addition, infrastructure projects originator project "true sale" of assets to securitization, cut the risk of future cash income-generating projects and projects their risk assets to achieve a "bankruptcy-remote" to further protect the interests of investors . Third, asset securitization financing to ensure the safety of infrastructure projects. Most of the infrastructure projects in the field relating to the national economy of a country, the use of other financing methods, such as BOT approach to infrastructure projects typically require the control of the project to foreign investors, while foreign investors may disregard the characteristics of the project itself, not from the project sustainable development point of view to develop operational projects, just to recover the investment in the short term, leading to a negative impact on the future operation and maintenance of the project. The use of asset securitization financing infrastructure projects, bonds issued during the ownership of assets, implement asset securitization project owned by SPV all but business decision-making is still owned by the original project interests people, so the host will be able to maintain the operation of the project control to ensure the safety of the project construction and operation. Fourth, since the SPV securitized assets is "true sale", so after the sale of assets can be 
removed from the balance sheet in order to achieve sheet financing, to avoid the restrictions originator's asset quality. Fifth, through the issuance of asset securitization infrastructure projects Asset-Backed Securities, will not have the liquidity infrastructure stock assets into high credit rating, benefiting more stable marketable securities. Originator can get the funds available and put into new infrastructure projects, thereby allowing liquidity and profitability of infrastructure assets has been greatly improved.

\section{Operation of infrastructure asset securitization financing}

\section{Choose the underlying asset}

Infrastructure asset securitization financing, it must first ensure that infrastructure projects having securities resistance. Non-operating items of infrastructure projects is provided having a non-exclusionary and non-competitive features, is a typical pure public goods, its failure to develop the possibility of charging appropriate prices do not exist (or charges too costly, making it impossible), generally only way to take the government to provide free public production. Therefore, such projects can not generate predictable cash flows, it is not suitable as the basis for asset securitization assets. Management of infrastructure projects is a quasi-public goods, itself can completely recover the investment. Infrastructure projects such as electricity, telecommunications and toll roads, bridges and other future cash flow is stable, reliable, and less risky, more suitable as an asset securitization financing of the underlying asset.

\section{Infrastructure asset securitization financing SPV formation}

Asset securitization process involves many legal subjects. Wherein the SPV in its central position in the legal relationship. SPV is a basic condition for the successful formation and asset securitization can be a key factor in the successful operation. It is the issue of the rights of legitimate owners or Asset-Backed Securities underlying asset disposal, assets of securities issuers and debt repayment maturity of people, but it is also the use of the issue of asset securitization financing subrogation and related financing matters entrusted debtor, is mainly engaged in a single business : purchase of securitized assets, equity consolidation of accounts, and use it as a security issue securities. Usually SPV mainly in the form of trusts, and limited partnerships and other companies. The agency can obtain authoritative international credit rating agency granted by a higher credit rating, usually AAA or AA.

\section{Problems and Solutions in China's infrastructure asset securitization financing}

\section{About SPV formation}

In China, mature SPV structure has not yet formed. Mature market economy countries, SPV mainly trusts, corporations and limited partnerships and other forms. China "Partnership Enterprise Law" has not yet specified the form of limited partnership, there is no provision in the form of partnership. Therefore, China Asset Securitization SPV no legal basis to build on in the form of a limited partnership. China's "Trust Law" to make special purpose trust (SPT) established feasible. But "Trust and Investment Company Capital Trust Interim Measures," China Article 4, paragraph 2, "trust and investment company for capital trust business when ... ... can not issue bonds, investment certificates shall not issue commission, agency investment certificates, beneficiary certificates, negotiable Securities on behalf of custody orders and other ways to raise funds, for debt service. " This allows the asset securitization financing trust-based SPV bonds issued legal obstacles. The type of SPV company established in China, there are some obstacles. China "Company Law" to require a higher joint stock limited company, set up complicated procedures, combined with corporate bond issuance requirements are relatively high, so that the company type SPV formation costs. In view of this, in 2004 the National Development Bank reported assets securitization package of programs to address the problem of who to play SPV, has been submitted to the State by the People's Bank of China. In this scheme, the CDB play SPV, commercial banks based on their lending risk, different benefits package sold to SPV, the SPV and then depending on the circumstances of these assets, design a different duration and yield securities sold concurrent 
investment By. This design, the central bank to achieve a respected sheet financing, the Bank completed the sale through the behavior and the risk of isolation, the proceeds among commercial banks, China Development Bank and distributed to investors.

\section{About the tax system aspects}

Tax issues and infrastructure projects related to asset securitization financing, including asset sales tax items, SPV income tax and tax and other investors. When promoters SPV "true sale" of assets, and any income generated may have credited. Income tax assets and the income statement, while also generating sales tax and stamp duty. Tax on SPV will greatly increase the cost of issuing bonds. While income investors may also have to pay income tax. It is difficult to avoid duplicate taxation asset securitization development will bring great obstacles. Chinese Ministry of Finance, State Administration of Taxation file (2001) 10 of the China's four state-owned asset management companies use asset securitization means of loans and collateral eligible for tax incentives disposal. It can be taken to set up Sino-foreign cooperation project company, Sino-foreign cooperative enterprises to take advantage of preferential tax treatment. However, further development and refinement of special tax benefits and special provisions of the SPV for transactions such as tax incentives to promote the provision is the fundamental way to regulate the operation of the infrastructure asset securitization financing.

In addition, the existing legal regime on the nature of the product and asset securitization issuance and listing conditions, disclosure of information etc. has not yet made a clear definition, there is no asset securitization regulation and coordination of the specialized agencies, there is no asset securitization special legislation. These infrastructure projects have hindered the use of asset securitization financing development. Currently, the correct understanding of the relationship between asset securitization law multiplicity and complexity, accurately grasp the securitization process in all key areas, in order to take different measures for different sectors in accordance with relevant laws, so as to ensure asset securitization norms and efficient. Of course, in order to promote the development of asset securitization, the Chinese legislature should develop a new law or to make corresponding adjustments to the existing laws.

\section{About Forex question of balance}

Since the SPV to issue bonds in the international high-end security market, which is bound to pay off the principal and interest of bonds abroad to use foreign currency exchange. Using asset securitization to raise funds for the construction of infrastructure projects, and the project itself was less export products, so the proceeds mainly for the domestic currency, which necessarily need to convert local currency into foreign currency, it will face a exchange rate risk. The RMB exchange rate stability, increase China's foreign exchange reserves can enhance the confidence of foreign investors to invest

\section{Summary}

Asset securitization has clever risk management mechanism and reduce financing costs of financial functions, and supply chain finance has a unique asset risk control mechanism; analysis of two financing principle of the method, from the perspective of complementarity and integration of innovation proposed under the supply chain environment asset securitization new model SMEs. The main conclusions are the following two points: (1) supply chain and operational characteristics, improve credit asset securitization and build the foundation of the asset pool. Based on supply chain structure to build a credit risk control mechanisms underlying assets, the formation can be securitized pool of assets in the form of commercial paper issued and outstanding in the capital markets, asset securitization of SME innovation model; (2) innovation model different from supply chain finance, mainly to solve the deficiencies of the prior bank-centered model of indirect financing, funds from the capital market as the supply side, to achieve adequate supply of capital, low risk and low financing costs and other direct financing objectives. 


\section{References}

[1] Dj.M. Maric, P.F. Meier and S.K. Estreicher: Mater. Sci. Forum Vol. 83-87 (1992), p. 119

[2] M.A. Green: High Efficiency Silicon Solar Cells (Trans Tech Publications, Switzerland 1987).

[3] Y. Mishing, in: Diffusion Processes in Advanced Technological Materials, edtied by D. Gupta Noyes Publications/William Andrew Publising, Norwich, NY (2004), in press.

[4] G. Henkelman, G.Johannesson and H. Jónsson, in: Theoretical Methods in Condencsed Phase Chemistry, edited by S.D. Schwartz, volume 5 of Progress in Theoretical Chemistry and Physics, chapter, 10, Kluwer Academic Publishers (2000).

[5] R.J. Ong, J.T. Dawley and P.G. Clem: submitted to Journal of Materials Research (2003)

[6] P.G. Clem, M. Rodriguez, J.A. Voigt and C.S. Ashley, U.S. Patent 6,231,666. (2001)

[7] Information on http://www.weld.labs.gov.cn 